\title{
Strategies on Promoting Vocational Guidance in Universities
}

\author{
Hongjin $\mathrm{Fu}^{1, a}$, Yunfang $\mathrm{Li}^{2, b}$ \\ ${ }^{1}$ School of Informatics, Linyi University, Linyi, Shandong 276005, China, \\ ${ }^{2}$ School of Mechanical Engineering, Linyi University, Linyi, Shandong 276005, China. \\ afuhongjin@lyu.edu.cn, bliyunfang@lyu.edu.cn
}

Keywords: Role; College student; Counselors; Construction; Study Style.

\begin{abstract}
It is necessary to set up a special service system focusing on vocational guidance to promote the scientific development of vocational guidance and create a good guidance service for students to make plans on career development. This paper probes into the problems and establish conditions of guidance system of employment in university, and further put forward some suggestions on how to promote the work about employment guidance in university.
\end{abstract}

\section{Introduction}

The development of vocational guidance has become an important part of the development in higher education. The present work of employment guidance in universities should be carried out complying with the development needs of market economy. And it is urgent need to establish a special service system of vocational guidance that through the establishment of the scientific teaching concept on vocational guidance to promote the scientific development of vocational guidance. Persist harmonious employment view and implement scientific career guidance to help the students to draw up the reasonable professional development plan to realize the harmony of students and the post, the employment of students and the social development [1][2]. In the establishing process of the vocational guidance, it should make the appropriate guidance on the correct employment concept, employment policies and employment psychology, students should be guided with the correct concept of employment, employment policy guidance, and information consultation so as to provide adequate assurance for improve the professional skills in employment of college students. However, there are many constraints in the teaching process of career guidance in employment guidance and career guidance content in the current stage. Therefore, it should gradually optimize and establish the scientific concept work system for vocational guidance to improve the employment rate and competitiveness of college graduates in fundamental significance.

\section{The Present Situation of Vocational Guidance in University}

The curriculum system of vocational guidance in colleges and universities is not complete. At the present stage, the development of vocational guidance in Colleges and universities in our country is more of a career guidance for students who are about to graduate, while is not a scientific and widely vocational guidance for all students. The establishment of such vocational guidance education system also brings some restriction to the development of career guidance, which bring constraint to the development of career guidance. There will emerge hurried, temporary guidance that causing short hours, assault and other problems in the establishment and the implementation of curriculum model about the professional guidance measures. Such system does not provide enough time to guide the graduate students to carry out scientific and reasonable career plan, so it fail to achieve the ideal results of vocational guidance in colleges and universities.

The practical environment of high schools affects the establishment of vocational guidance system. We face with the limitations from educational environment, the financial pressure, the examination requirements and other problems in the process of the establishment of the whole educational system. The appearance of these factors indirectly affects the establishment of vocational guidance system 
and the development of vocational guidance in colleges and universities, resulting in high quality of students and the heavy task of academic education. For college graduates, the knowledge and skills learned in school cannot fully meet the needs of economic development and social demands, which has brought some constraints on the establishment of vocational guidance system of the whole high schools.

Lack of guidance on career design and planning of students. At present, the majority of students lack the awareness of career path planning and relevant theoretical knowledge, without specific orientation and planning for their future vocational development. Moreover, the vocational guidance domestic university is mainly guiding the students to be employed in the short term, as a result, teachers do not help students to fully understand themselves, to determine the direction of development of employment combined with social environment and other external factors, causing students can not propose feasible career development plan that do not reflect the maximum value of life.

The theoretical research of career guidance in universities in our country is slow. To establish a theory and mode of vocation guidance is an urgent issue in the changing economic environment and with diversified needs of graduates. Employment guidance in our country is relatively weak in theoretical research as well as empirical studies. In the teaching process of vocational guidance courses, the professional guidance teachers have some restrictions on the cognition of career guidance work and the understanding on the basic content is relatively simple, which cannot fully display the basic goal of higher education in the establishing process of the system in career guidance. Moreover, the professional guidance teachers also have some limitations in the cognition process of career guidance. Meanwhile, the teaching base is very weak that no professional guidance teams are established and the attention degree of high school on teachers teams of vocational guidance is low, which affect the research process on theory of vocational guidance for university. The ineffective work of employment guidance and career counseling in universities is caused by the lack of an effective theory and specific ideas for career guidance. Therefore, universities must continue to strengthen the establishment of career guidance team, and continuously strengthen the theory and practice of exploration, and effectively improve the quality of educators in the work of vocational guidance.

Failed to carry out effective entrepreneurial guidance for university students. Entrepreneurship is an important part of graduate employment in high schools. In the era of national entrepreneurship and new times of overall innovations, the departments of vocational guidance in colleges and universities should not only guide the employment of students, but also provide scientific and reasonable business guide for undergraduates. Teachers can guide the college student to write their own business plan with the support and assistance of schools. We think by writing the business plan, students can understand the difficulties and risks on the road of the future business, which can be the theoretical guidance for future entrepreneurial practice. It also can make students find out whether he can be a successful entrepreneur [3].

\section{Conditions for the Establishment of Vocational Guidance System in University}

For college graduates that the first time to enter the labor market and face the employment problems, it needs to establish a dedicated career guidance service system to serve college students to promote their employment.

Firstly, it should gradually increase the curriculums of vocational guidance, which provides a prerequisite for career guidance system. The development of career guidance curriculum is of great significance in terms of enhancing the practical efficiency of career guidance in universities, meeting career plan and development of human life of students and promoting the interaction between talents training and social need.

Second, employment information service system, including employment information networks of education sector in various provinces, autonomous regions, talent recruitment website, comprehensive information platform, etc. provides effective information platform for career 
guidance. It is an urgent important task to further establish and improve career guidance and employment information service agencies to provide high quality business services employment and help students to establish a correct concept of employment.

Third, according to the own quality of each student combined with the professional situation, the choice of career for university students will be very different. It will provide humanistic basis for the establishment of career guidance system.

Fourth, different industries have different demands for graduates, which provides effective goals and guidance for the development of vocational guidance in universities. The school needs to integrate itself with the actual applications based on the sector demands.

\section{Suggestions on Promoting the Development of Vocational Guidance in Universities}

To establish and perfect the service system of employment guidance in so as to make it an integral part of university education. In the process of education in universities, to raise the employment rate of college graduates in the fundamental sense, it should establish a systematic model of employment guidance during the professional knowledge education. Just from the beginning of entering college, it should carry out the related education courses about occupation career design to cultivate the employment awareness of students, leading students to clearly realize the severe employment situation of university graduates. Moreover, in the process of career guidance teaching, it should guide the student gradually change the traditional concept of employment that let students convert the pressure of employment into the motivation of learning. In the second year of college, the students should be trained to form the correct outlook on life, values and the basic concept of employment, so as to provide sufficient guarantee for the development of students. In the third year, university should strengthen the training of vocational skills of students, improve their professional skills, and enhance their employability. In the last year, students should be provided with professional pre- employment training to improve their employment skills. University should establish a scientific employment guidance system to help students establish a scientific and rational future career development direction [4] [5].

To increase the policy and financial support for vocational guidance in universities. Through the establishment of a reasonable policy of employment guidance to led the university to realize its importance. Meanwhile, through the allocation of funds, to increase the funding investment to provide strong financial support for the employment guidance work in university. Besides, it should strengthen the training of vocational guidance staff to improve their overall quality and improve the effectiveness of vocational guidance, which will strengthen the theoretical research and development of vocational guidance.

Universities should strive to expand the channels and establish a diversified model for employment guidance. In the process of establishing the employment guidance system, it can establish a diversified and socialized employment guidance mode. For example, offering special instruction courses for students to teach professional expertise for vocational guidance; inviting outstanding alumni to conduct professional lectures professional seminars, based on their choice of employment and explanation on the real experience of the employment to provide relevant experience for reference and inspiration .

Make full use of the existing occupation information interactive platform. For the information career interactive platform, the main purpose is to make the students timely know the changes of the career development of their major that to fully achieve the information interaction in the fundamental sense. First, to make full use of the employment information networks of various provinces and cities, so that students can collect employment information timely. Thus, employers and graduates can make effective communication and exchange information to broaden employment channels and deliver professional employment information to students. Second, we can take advantage of various networks, Websites and other new media have main advantages in the process of personnel training to improve the reputation of universities and attract more units to recruit [6]. Third, to establish a new 
model of school-enterprise cooperation, so that students can access to the latest cutting-edge technology, to understand the latest career needs and make accurate career planning and selection.

Widely offer enterprise guidance courses in universities. In our country, the rate of successful entrepreneurship is low, one of the important reasons is the imperfection of college students' entrepreneurial service system. First of all, to carry out a wide range of entrepreneurship guidance courses for students to conduct scientific and rational business guidance and enhance the entrepreneurial awareness of students. Then, help students to conduct a reasonable appraisal to entrepreneurial projects, and provide full support including entrepreneurship theory, policy and funding for students entrepreneurship. Therefore, students not only complete the learning of professional knowledge, but also increase the entrepreneurial experience, which make full response to the policy of central government of mass entrepreneurship and innovation, which are regarded as a new engine fueling China economic growth. Third, by inviting the entrepreneurial success of alumni to speech and impart entrepreneurial success experience, so as to inspire the entrepreneurial enthusiasm of university students and open up a new way for student employments [7] [8] [9][10].

\section{Summary}

The ineffective work of employment guidance and career counseling in universities is caused by the lack of an effective theory and specific ideas for career guidance. Therefore, universities should pay more attention to vocational guidance work and take effective measures to promote the development of vocational guidance, to provide effective guidance in students' employment, career development and self-employment to improve the employment rate and entrepreneurship rate of students.

\section{References:}

[1] Shaomei $\mathrm{Wu}$. Innovative exploration of the employment guidance education in career planning of college students. China Education Innovation Herald. 0 (35) (2010) 22-23.

[2] Yugui Jia, Jiabin Qi, Jie Wang. Snalysis on content and practical significance of vocational guidance education system in Colleges and Universities. Journal of Higher Education. 0 (1) (2016) 32-35.

[3] Liu Wei. How to improve college students' career guidance effectiveness and efficiency. Journal of Jiamusi Vocational Institute. 0 (1) (2016) 269-270.

[4] Ping Wu,Mingguo Ling,Siying Li. How to Promote the Development of the Vocational Guidance Work in College and Universities. 30 (1) (2016) 123-125

[5] Jing Su, Yichen Wang. Analysis on vocational guidance service system in Colleges and Universities. People's Tribune. 0 (29) (2010) 226-227.

[6] Yujiao Yang, Congcong Xu, Jiahui Li. The exploration and practice of Career Guidance College Counselors under the network environment. Science \& Technology Information. 0 (10) (2016) 117-118.

[7] Daimei Wang, Shuxian Lin. Research on Project Management of Vocational Guidance Course in Higher Vocational Colleges. Journal of Ningbo Polytechnic. 20 (2) (2016) 35-40.

[8] Dan Chen, Research on vocational guidance curriculum system in higher vocational college taking employment as direction. Journal of Wuhan Bioengineering Institute. 6(3) (2010) 196-200.

[9] Yifan Yu. Analysis on college employment guidance course and career development of college students. Science \& Technology Information. 0 (33) (2016) 150-151.

[10] Ruihua Tang. Study on reform of the career development and employment guidance curriculum of students. China University Students Career Guide. 0 (4) (2014) 52-55. 